\title{
TITLE:
}

\section{Liquefaction of beech wood in various supercritical alcohols}

AUTHOR(S):

Yamazaki, Jun; Minami, Eiji; Saka, Shiro

CITATION:

Yamazaki, Jun ...[et al]. Liquefaction of beech wood in various supercritical alcohols. Journal of Wood Science 2006, 52: 527-532

ISSUE DATE:

2006-12

URL:

http://hdl.handle.net/2433/250165

\section{RIGHT:}

This is a post-peer-review, pre-copyedit version of an article published in Journal of Wood Science. The final authenticated version is available online at: http://dx.doi.org/10.1007/s10086-005-0798-4.; This is not the published version. Please cite only the published version.; この論文は出版社版でありません。引用の際には出版社版をご磼認じ 利用ください。 


\section{Title page}

Original article

Title

Liquefaction of beech wood in various supercritical alcohols

Authors

Jun Yamazaki • Eiji Minami • Shiro Saka

Jun Yamazaki • Eiji Minami • Shiro Saka $(\bowtie)$

Department of Socio-Environmental Energy Science, Graduate School of Energy Science, Kyoto University, Yoshida-honmachi, Sakyo-ku, Kyoto 606-8501, Japan

Tel/Fax: +81-(0) 75-753-4738

E-mail: saka@energy.kyoto-u.ac.jp

*This study was presented in part at the 55th Annual Meeting of the Japan Wood Research Society in Kyoto, Japan, March 16-18, 2005.

Keywords : Supercritical fluid $\cdot$ Alcohol $\cdot$ Japanese beech $\cdot$ Lignin $\cdot$ Cellulose 
Abstract: The liquefaction of Japanese beech (Fagus crenata Blume) was studied with various straight-chain alcohols in subcritical or supercritical state using a batch-type reaction vessel to obtain liquid fuel from lignocellulosics. Under the reaction condition of $270^{\circ} \mathrm{C}$, beech wood was liquefied to some extent in any alcohol with about 50 65\% of insoluble residue left after the treatment for $30 \mathrm{~min}$. Under the condition of $350^{\circ} \mathrm{C}$, however, more than $90 \%$ of wood was decomposed and liquefied in any alcohol. Alcohol with the longer alkyl chain could have lignocellulosics liquefied in the shorter reaction time. Since many kinds of alcohols such as methanol and ethanol can be produced from biomass, the 100\% biomass-based liquid fuel can be prepared by supercritical alcohol technology when using such bioalcohols. 


\section{Introduction}

Due to human activities of mass-production, mass-consumption and mass-waste since early 20th century, environmental issues such as global warming and acid rain have become increasingly serious in the world. In current environmental situations, environmentally friendly biomass resources such as lignocellulosics should be utilized effectively as an alternative to fossil resources. Although biomass resources are renewable, carbon-neutral and remarkably massive in amount, they are so bulky and difficult to transport, handle and reserve. Therefore, an appropriate methodology is required to convert them into low molecular weight products such as liquid fuels and valuable chemicals.

Supercritical fluid is a candidate for the chemical conversion of lignocellulosics due to its unique properties. As is well known, supercritical water (critical temperature; $T_{\mathrm{c}}=374^{\circ} \mathrm{C}$, critical pressure; $P_{\mathrm{c}}=22.1 \mathrm{MPa}$ ) treatment for cellulosic samples has been studied by various groups to obtain saccharides for subsequent fermentation to ethanol. ${ }^{1-5}$ However, these hydrolyzed products are further decomposed into various volatile and gaseous compounds in severe conditions of supercritical water. ${ }^{6-9}$

On the other hand, alcohols such as methanol $\left(T_{\mathrm{c}}=239^{\circ} \mathrm{C}, P_{\mathrm{c}}=8.09 \mathrm{MPa}\right)$ and ethanol $\left(T_{\mathrm{c}}=243^{\circ} \mathrm{C}, P_{\mathrm{c}}=6.38 \mathrm{MPa}\right)$ have been also studied for supercritical fluid treatment of lignocellulosics. ${ }^{10-12}$ Since these alcohols have relatively in lower critical temperature and pressure than those of water, they can offer the milder conditions for the reaction. In addition, these alcohols are expected to readily dissolve well relatively high molecular weight products from cellulose, hemicelluloses and lignin due to the lower dielectric constants than that of water.

Actually, McDonald et al. ${ }^{10}$ and Poier et al. ${ }^{11}$ have reported a good conversion of woody biomass into liquefied products by supercritical methanol treatment. In previous works, 
furthermore, our research group has studied wood liquefaction and decomposition behaviors of its components; cellulose, hemicelluloses and lignin in supercritical methanol, finding that more than $90 \%$ of wood could be decomposed and liquefied under the condition of $350^{\circ} \mathrm{C} / 43 \mathrm{MPa} .{ }^{13-16}$ However, a prolonged treatment of about 30 min was required for the liquefaction of wood in the case of methanol. ${ }^{15}$

Regarding other alcohols, Köll et al. ${ }^{17}$ conducted a study of delignification by using methanol, ethanol, 1-propanol and other organic solvents in their supercritical states at around $250 \sim 280^{\circ} \mathrm{C}$, and reported that the highest ratio of lignin/carbohydrate degradation was achieved with ethanol. However, since only few studies have been made on the wood liquefaction in supercritical alcohols, its knowledge is currently limited.

In this study, therefore, the possibility of wood liquefaction with various alcohols was discussed in sub/supercritical state to achieve a high conversion rate with an appropriate reaction condition. The obtained liquid products would be used directly as liquid fuel because alcohol itself is a good fuel. In addition, many kinds of alcohols can be produced from biomass; for example, methanol synthesized from hydrogen and carbon monoxide gasified from biomass, while ethanol and butanol fermented from biomass saccharides, octanol and decanol from hydrogen reduction of vegetable oils, and so on. Thus $100 \%$ biomass-based liquid fuel and chemicals can be created when using such bioalcohols. Additionally, different alcohols have different fuel properties; one with the longer alkyl chain has a higher calorific value and cetane number. Therefore, various types of biofuels can be achieved by changing a kind of alcohol. 


\section{Materials and methods}

Supercritical alcohol treatment

As woody biomass sample, wood flour of Japanese beech (Fagus crenata Blume) passed through 80 mesh (about $280 \mu \mathrm{m}$ ) was subjected to supercritical alcohol treatment. As a solvent, six kinds of straight-chain monohydric alcohols (methanol, ethanol, 1-propanol, 1-butanol, 1-octanol and 1-decanol) were purchased from Nacalai-tesque, Kyoto.

To start the treatment, approximately 4.9mL of alcohol was placed with $150 \mathrm{mg}$ of the wood flour in a $5 \mathrm{~mL}$ reaction vessel, which was then immersed in a molten tin bath preheated to $270^{\circ} \mathrm{C}$ or $350^{\circ} \mathrm{C}$. The reaction pressure, which is uncontrollable in the batch-type reaction vessel, depended on reaction temperature and type of alcohols. The experimental conditions for respective alcohols are shown in Table 1 with their critical points. After an adequate reaction time, the vessel was moved to a water bath to quench the reaction. The obtained reaction mixture was then filtered with a $0.2 \mu$ m membrane filter to separate alcohol-soluble portion from alcohol-insoluble residue.

Analytical methods

Analytical methods for the alcohol-insoluble residue and alcohol-soluble portion were the same as those in our previous work. ${ }^{15}$ For the residue, Klason lignin content and acid-soluble lignin were determined, while the amounts of constituent monosaccharides were analyzed by high performance liquid chromatography (HPLC) for the clear filtrate from acid hydrolyzates obtained in the Klason lignin determination process. The cellulose and 
hemicelluloses contents in the alcohol-insoluble residue were then estimated, based on the amounts of glucose and other monosaccharides, respectively.

On the other hand, the alcohol-soluble portion was directly analyzed by gel permeation chromatography (GPC) and HPLC. ${ }^{15}$ Some reaction products were isolated using preparative thin layer chromatography (TLC) on silica gel plate (Kieselgel $60 \mathrm{~F}_{254}$, Merck) and analyzed by proton nuclear magnetic resonance $\left({ }^{1} \mathrm{H}-\mathrm{NMR}\right)$ spectroscopy, in which the spectra were recorded in $\mathrm{CDCl}_{3}$ using a Brucker $\mathrm{AC}-300(300 \mathrm{MHz})$ spectrometer with tetramethylsilane as an internal standard. Chemical shift $\delta(\mathrm{ppm})$ and coupling constant $(\mathrm{Hz})$ of the isolated products were obtained as below:

Coniferyl alcohol $\gamma$-ethyl ether (trans form): ${ }^{1} \mathrm{H}-\mathrm{NMR}\left(\mathrm{CDCl}_{3}, 300 \mathrm{MHz}\right) \delta: 1.25(3 \mathrm{H}, \mathrm{t}, \mathrm{J}=7.0$, $\left.-\mathrm{CH}_{3}\right), 3.54\left(2 \mathrm{H}, \mathrm{q}, \mathrm{J}=7.0,-\mathrm{OCH}_{2}-\right), 3.90\left(3 \mathrm{H}, \mathrm{s},-\mathrm{OCH}_{3}\right), 4.12\left(2 \mathrm{H}, \mathrm{d}, \mathrm{J}=6.2, \mathrm{C}_{\gamma}-\mathrm{H}\right), 5.62(1 \mathrm{H}, \mathrm{s}$, -OH), $6.15\left(1 \mathrm{H}, \mathrm{dt}, \mathrm{J}=15.8,6.2, \mathrm{C}_{\beta}-\mathrm{H}\right), 6.52\left(1 \mathrm{H}, \mathrm{d}, \mathrm{J}=15.8, \mathrm{C}_{\alpha}-\mathrm{H}\right), 6.83-6.93$ (3H, m, aromatic $\mathrm{H})$.

Sinapyl alcohol $\gamma$-ethyl ether (trans form): ${ }^{1} \mathrm{H}-\mathrm{NMR}\left(\mathrm{CDCl}_{3}, 300 \mathrm{MHz}\right) \delta: 1.25(3 \mathrm{H}, \mathrm{t}, \mathrm{J}=7.0$, $\left.-\mathrm{CH}_{3}\right), 3.55\left(2 \mathrm{H}, \mathrm{q}, \mathrm{J}=7.0,-\mathrm{OCH}_{2}-\right), 3.90\left(6 \mathrm{H}, \mathrm{s},-\mathrm{OCH}_{3}\right), 4.12\left(2 \mathrm{H}, \mathrm{d}, \mathrm{J}=6.3, \mathrm{C}_{\gamma}-\mathrm{H}\right), 5.52(1 \mathrm{H}, \mathrm{s}$, -OH), $6.17\left(1 \mathrm{H}, \mathrm{dt}, \mathrm{J}=15.8,6.2, \mathrm{C}_{\beta}-\mathrm{H}\right), 6.51\left(1 \mathrm{H}, \mathrm{d}, \mathrm{J}=15.8, \mathrm{C}_{\alpha}-\mathrm{H}\right), 6.63(2 \mathrm{H}, \mathrm{s}$, aromatic $\mathrm{H})$. Coniferyl alcohol $\gamma$-propyl ether (trans form): ${ }^{1} \mathrm{H}-\mathrm{NMR}\left(\mathrm{CDCl}_{3}, 300 \mathrm{MHz}\right) \delta: 0.95(3 \mathrm{H}, \mathrm{t}, \mathrm{J}=7.4$, $\left.-\mathrm{CH}_{3}\right), 1.56-1.7\left(2 \mathrm{H}, \mathrm{m},-\mathrm{CH}_{2}-\right), 3.44\left(2 \mathrm{H}, \mathrm{t}, \mathrm{J}=6.8,-\mathrm{OCH}_{2}-\right), 3.90\left(3 \mathrm{H}, \mathrm{s},-\mathrm{OCH}_{3}\right), 4.11(2 \mathrm{H}, \mathrm{d}$, $\left.J=6.2, C_{\gamma}-H\right), 5.61(1 \mathrm{H}, \mathrm{s},-\mathrm{OH}), 6.15\left(1 \mathrm{H}, \mathrm{dt}, \mathrm{J}=15.8,6.2, \mathrm{C}_{\beta}-\mathrm{H}\right), 6.52\left(1 \mathrm{H}, \mathrm{d}, \mathrm{J}=15.8, \mathrm{C}_{\alpha}-\mathrm{H}\right)$, 6.86-6.94 (3H, m, aromatic H).

Sinapyl alcohol $\gamma$-propyl ether (trans form): ${ }^{1} \mathrm{H}-\mathrm{NMR}\left(\mathrm{CDCl}_{3}, 300 \mathrm{MHz}\right) \delta: 0.95(3 \mathrm{H}, \mathrm{t}, \mathrm{J}=7.4$, $\left.-\mathrm{CH}_{3}\right), 1.56-1.7$ (2H, m, - $\left.\mathrm{CH}_{2}-\right), 3.44$ (2H, t, J=6.7, $\left.-\mathrm{OCH}_{2}-\right), 3.90\left(6 \mathrm{H}, \mathrm{s},-\mathrm{OCH}_{3}\right), 4.12(2 \mathrm{H}, \mathrm{d}$, $\left.J=6.2, C_{\gamma}-H\right), 5.51(1 \mathrm{H}, \mathrm{s},-\mathrm{OH}), 6.17\left(1 \mathrm{H}, \mathrm{dt}, \mathrm{J}=15.8,6.2, \mathrm{C}_{\beta}-\mathrm{H}\right), 6.51\left(1 \mathrm{H}, \mathrm{d}, \mathrm{J}=15.8, \mathrm{C}_{\alpha}-\mathrm{H}\right)$, $6.63(2 \mathrm{H}, \mathrm{s}$, aromatic H). 
Coniferyl alcohol $\gamma$-butyl ether (trans form): ${ }^{1} \mathrm{H}-\mathrm{NMR}\left(\mathrm{CDCl}_{3}, 300 \mathrm{MHz}\right) \delta: 0.93(3 \mathrm{H}, \mathrm{t}, \mathrm{J}=7.3$, $\left.-\mathrm{CH}_{3}\right), 1.32-1.46\left(2 \mathrm{H}, \mathrm{m},-\mathrm{CH}_{2}-\right), 1.56-1.65\left(2 \mathrm{H}, \mathrm{m},-\mathrm{CH}_{2}-\right), 3.48$ (2H, t, J=6.6, $\left.-\mathrm{OCH}_{2}-\right), 3.90$ (3H, s, $\left.-\mathrm{OCH}_{3}\right), 4.11\left(2 \mathrm{H}, \mathrm{d}, \mathrm{J}=6.2, \mathrm{C}_{\gamma}-\mathrm{H}\right), 5.61(1 \mathrm{H}, \mathrm{s},-\mathrm{OH}), 6.15\left(1 \mathrm{H}, \mathrm{dt}, \mathrm{J}=15.8,6.2, \mathrm{C}_{\beta}-\mathrm{H}\right)$, $6.52\left(1 \mathrm{H}, \mathrm{d}, \mathrm{J}=15.8, \mathrm{C}_{\alpha}-\mathrm{H}\right)$, 6.83-6.92 (3H, m, aromatic H).

Sinapyl alcohol $\gamma$-butyl ether (trans form): ${ }^{1} \mathrm{H}-\mathrm{NMR}\left(\mathrm{CDCl}_{3}, 300 \mathrm{MHz}\right) \delta: 0.93(3 \mathrm{H}, \mathrm{t}, \mathrm{J}=7.4$, $\left.-\mathrm{CH}_{3}\right), 1.33-1.47$ (2H, m, - $\left.\mathrm{CH}_{2}-\right)$, 1.56-1.65 (2H, m, - $\left.\mathrm{CH}_{2}-\right)$, 3.48 (2H, t, J=6.5, $\left.-\mathrm{OCH}_{2}-\right)$, 3.90 (6H, s, $\left.-\mathrm{OCH}_{3}\right), 4.11\left(2 \mathrm{H}, \mathrm{d}, \mathrm{J}=6.2, \mathrm{C}_{\gamma}-\mathrm{H}\right), 5.51(1 \mathrm{H}, \mathrm{s},-\mathrm{OH}), 6.16\left(1 \mathrm{H}, \mathrm{dt}, \mathrm{J}=15.8,6.2, \mathrm{C}_{\beta}-\mathrm{H}\right)$, $6.50\left(1 \mathrm{H}, \mathrm{d}, \mathrm{J}=15.8, \mathrm{C}_{\alpha}-\mathrm{H}\right), 6.63(2 \mathrm{H}, \mathrm{m}$, aromatic $\mathrm{H})$.

\section{Results and Discussion}

Decomposition behaviors of beech wood

Figure 1 shows the changes in the mass of alcohol-insoluble residues of beech wood after treated in various supercritical alcohols at $270^{\circ} \mathrm{C}$ and $350^{\circ} \mathrm{C}$. Under the condition of $270^{\circ} \mathrm{C}$ (a), beech wood was liquefied to some extent in any alcohol but 50 65\% of wood was always recovered in all cases even after the treatment for $30 \mathrm{~min}$. In the shorter reaction time less than 10 min, the residue slightly increased in amount with the length of alkyl chain of alcohol being longer. In contrast, the residue decreased in amount with the length of alcohol being longer in prolonged reaction time over $10 \mathrm{~min}$. Under the condition of $350^{\circ} \mathrm{C}(\mathrm{b})$, however, beech wood was decomposed efficiently and more than $90 \%$ of wood was liquefied eventually in any alcohol. In addition, it was apparent that alcohol with the longer alkyl chain exhibited a faster wood liquefaction. In the case of methanol and ethanol, about 30 min of the treatment was required to liquefy $90 \%$ of wood, while $20 \mathrm{~min}, 10 \mathrm{~min}$ and only $3 \mathrm{~min}$ treatments were, 
respectively, required for 1-propanol, 1-butanol and 1-octanol. However, 1-decanol produced slightly much residue, compared with 1-octanol, thus it can be concluded that 1-octanol is the most efficient alcohol for the wood liquefaction among ones used in this study.

Decomposition of wood components

Figures 2 and 3 show the chemical composition of cellulose, hemicelluloses and lignin in alcohol-insoluble residue after treated in various alcohols at $270^{\circ} \mathrm{C}$ and $350^{\circ} \mathrm{C}$, respectively. Under the condition of $270^{\circ} \mathrm{C}$, it was found that cellulose was not decomposed in alcohols with short alkyl chain, whereas a small amount of cellulose could be liquefied in 1-octanol and 1-decanol. Furthermore, hemicelluloses and lignin were liquefied in all cases.

Under the condition of $350^{\circ} \mathrm{C}$, on the other hand, cellulose was decomposed successfully and liquefied eventually in any alcohol as well as hemicelluloses and lignin, which were almost decomposed and liquefied within a few minutes. It was also found that alcohols with the longer alkyl chain exhibited a faster liquefaction of cellulose.

Assuming that the liquefaction of wood components is the pseudo-first-order reaction, the liquefaction rate constants $(\kappa)$ were evaluated for cellulose, hemicelluloses and lignin, respectively. The results are shown in Figure 4. The liquefaction rate constant of cellulose was increased when the longer alkyl chain alcohol was used. In case of methanol, the rate constant of cellulose was estimated to be $1.25 \times 10^{-3} \mathrm{sec}^{-1}$, and increased to be $28.7 \times 10^{-3} \mathrm{sec}^{-1}$ for 1-decanol, whose value was about 20 times higher than that for methanol. Similarly, the rate constant of hemicelluloses tended to increase with the length of alkyl chain of alcohol, except for methanol. In contract, lignin had almost the same rate constant for any alcohol except for 1-decanol, which seemed to promote formation of char-like substances. 
Molecular weight distribution of the alcohol-soluble portion

Figure 5 shows the GPC chromatograms of the various alcohol-soluble portions after 30 min of the treatment at $350^{\circ} \mathrm{C}$. Although the chromatograms were recorded using both ultraviolet light detector (UV) and refractive index detector (RI), any difference was not observed between the molecular weight distributions by former and latter detectors.

The molecular weights of the liquefied products were in a range below about 3,500 in methanol, while 7,900 in ethanol, 8800 in 1-propanol, 11,000 in 1-butanol, 38,000 in 1-octanol and 42,000 in 1-decanol by a comparison with polystyrene standards. This result indicates that alcohol with the longer alkyl chain can dissolve higher molecular weight products, which cannot be liquefied in alcohol with the shorter one. Although the reason remained unclear why the efficiency for wood liquefaction changes depending on the kind of alcohol used, it should relate to solubility of the decomposed products with alcohol. It is, thus, suggested that the alcohol with the longer alkyl chain exhibits a faster wood conversion to liquefied products, due to its liquefaction of the higher molecular weight products.

Chemicals from lignin and cellulose

For the determination of lignin-derived products, HPLC analysis was carried out using a reversed phase column and ultraviolet light detector. Therefore, observed peaks were considered to be mainly lignin-derived ones because ordinary cellulose-derived products could not absorb the ultraviolet light except for 5-hydroxymethylfurfural (5-HMF) and furfural. Figure 6 shows the HPLC chromatograms of various alcohol-soluble portions as treated at $270^{\circ} \mathrm{C}$. The products observed at the retention times of 16.7 and 17.2 min were identified to be 
coniferyl alcohol (CA) and sinapyl alcohol (SA), respectively, after comparing them with the authentic samples. They appeared at the first stage of the reaction in any alcohol-soluble portion. In the case of methanol, other peaks were also observed at 28.6 and $29.0 \mathrm{~min}$, which were identified to be SA $\gamma$-methyl ether and CA $\gamma$-methyl ether by ${ }^{1} \mathrm{H}$-NMR analysis, respectively. In a similar manner, their $\gamma$-alkyl ethers were also found for respective alcohols used. In turn, other peaks observed at 36.9 and 37.4 min in retention times were increased. These newly formed products were identified to be 2,6-dimethoxy-4-(1-propenyl)phenol and isoeugenol in comparison with the authentic samples.

Based on these lines of evidence, degradation pathway of lignin in various supercritical alcohols was proposed as follows; lignin can be depolymerized to the lower molecular weight products by cleavage of ether linkages, ${ }^{14,16}$ and then dissolved in alcohol. However, lignin rich in the condensed linkages cannot be depolymerized sufficiently to liquefy in alcohol and it is recovered as the alcohol-insoluble residue. ${ }^{15,16}$ Part of the products liquefied is depolymerized into monomeric units of lignin such as CA, SA and their $\gamma$-alkyl ethers, which are further converted to other products as mentioned above.

On the other hand, Figure 7 shows the HPLC chromatograms of the methanol-soluble and ethanol-soluble portions as treated at $350^{\circ} \mathrm{C}$ for $30 \mathrm{~min}$. The analyses were carried out using the column for saccharides exclusive use (ULTRON PS-80P) so that observed peaks were considered to be mainly cellulose-derived ones. Actually, the compounds observed at 9.6, 10.1, 10.9, 11.7, and 21.9 min in retention times were identified to be methyl- $\beta$-D-glucoside (Me- $\beta$-glu), ethyl- $\beta$-D-glucoside (Et- $\beta$-glu), methyl- $\alpha$-D-glucoside (Me- $\alpha$-glu), ethyl- $\alpha$-D-glucoside (Et- $\alpha$-glu) and levoglucosan (LG), respectively, compared with the authentic samples. Although products in other alcohol-soluble portions remained unclear, it can be suggested that alkyl- $\alpha, \beta$-D-glucosides were generated by alcoholysis of cellulose in supercritical alcohol. Furthermore, 5-HMF and furfural, which were considered to be alkyl- $\alpha$, 
$\beta$-D-glucoside-derived compounds, were found in any alcohol-soluble portion as mentioned previously (Fig. 6).

According to the decomposition pathway of avicel proposed by Ishikawa and Saka, ${ }^{13}$ methanolysis of cellulose in supercritical methanol resulted in methylated cellotriose and methylated cellobiose, which are converted to methyl- $\alpha$ and $\beta$-D-glucoside. Subsequently, these products were anomerized each other, and as the treatment was prolonged, they were decomposed further to other products, such as LG, 5-HMF and furfural. For other alcohols, similar pathways should be given for cellulose decomposition.

\section{Conclusion}

The chemical conversion of beech wood in various supercritical alcohols was studied using a batch-type reaction vessel. Under the condition of $350^{\circ} \mathrm{C}$, all three cell wall components of wood were decomposed effectively in all cases and over $90 \%$ of wood was successfully liquefied. Among the alcohols used in this study, 1-octanol gave the fastest conversion of wood into liquefied products, achieving about 95\% conversion only by 3 min treatment. On the lignin-derived products, the main monomeric products were identified to be CA, SA and their $\gamma$-alkyl ethers, while on the cellulose-derived products, alkyl- $\alpha, \beta$-D-glucosides, LG, furfural and 5-HMF were identified in each alcohol-soluble portion. 


\section{Acknowledgments}

This research has been done by the Kyoto University 21 COE program, ”Establishment of COE on Sustainable Energy System” and under the research program for development of technologies for establishment of eco-system based on recycling in rural villages for the 21st century from the Ministry of Agriculture, Forestry and Fisheries, Japan. 


\section{References}

1. Adschiri T, Hirose S, Malaluan R, Arai K (1993) Noncatalytic conversion of cellulose in supercritical and subcritical water. J. Chem. Eng. Jpn. 26(6): 676-680

2. Sasaki M, Fang Z, Fukushima Y, Adschiri T, Arai K (2000) Dissolution and hydrolysis of cellulose in subcritical and supercritical water. Ind. Eng. Chem. Res. 39: 2883-2890

3. Sakaki T, Shibata M, Sumi T, Yasuda S (2002) Saccharification of cellulose using a hot-compressed water-flow reactor. Ind. Eng. Chem. Res. 41: 661-665

4. Saka S, Ueno T (1999) Chemical conversion of various celluloses to glucose and its derivatives in supercritical water. Cellulose 6: 177-191

5. Saka S, Konishi R (2001) Chemical conversion of biomass resources to useful chemicals and fuels by supercritical water treatment. In: Bridgwater AV (ed) Progress in Thermochemical Biomass Conversion. Blackwell Sci., Oxford, pp1338-1348

6. Antal MJ Jr., Mok WSL, Richards GN (1990) Four-carbon model compounds for the reactions of sugars in water at high temperature. Carbohydr. Res. 199: 111-115

7. Sasaki M, Adschiri T, Arai K (2004) Kinetics of cellulose conversion at $25 \mathrm{MPa}$ in suband supercritical water. AICHE J. 50(1): 192-202

8. Ehara K, Saka S (2002) A comparative study on chemical conversion of cellulose between the batch-type and flow-type systems in supercritical water. Cellulose 9: $301-311$

9. Ehara K, Saka S (2005) Decomposition behavior of cellulose in supercritical water, subcritical water, and their combined treatments. J. Wood Sci. 51(2): 148-153

10. McDonald EC, Howard J, Bennett B (1983) Chemicals from forest products by supercritical fluid extraction. Fluid Phase Equilib. 10: 337-344

11. Poirier MG, Ahmed A, Grandmaison JL, Kaliaguine CF (1987) Supercritical gas 
extraction of wood with methanol in a tubular reactor. Ind. Eng. Chem. Res. 26: 1738-1743

12. Labreque R, Kaliaquine S, Grandmaison JL (1984) Supercritical gas extraction of wood with methanol. Ind. Eng. Chem. Prod. Res. Dev. 23(1): 177-182

13. Ishikawa Y, Saka S (2001) Chemical conversion of cellulose as treated in supercritical methanol. Cellulose 8: 189-195

14. Tsujino J, Kawamoto H, Saka S (2003) Reactivity of lignin in supercritical methanol studied with various lignin model compounds. Wood Sci. Tech. 37(3-4): 299-307

15. Minami E, Saka S (2003) Comparison of decomposition behaviors of hard wood and soft wood in supercritical methanol. J. Wood Sci. 49(1): 73-78

16. Minami E, Kawamoto H, Saka S (2003) Reaction behaviors of lignin in supercritical methanol as studied with lignin model compounds. J. Wood Sci. 49(2): 158-165

17. Köll VP, Brönstrup B, Metzger J (1979) Thermal degradation of birch wood with supercritical gases (organic solvents) in a high-pressure, high-temperature flow apparatus: the liquefaction of wood and further evidence for an alternative cellulose pulp technology. Holzforsch. 33: 112-116 
Table 1. Critical points of various alcohols and reaction conditions in the batch-type vessel

\begin{tabular}{lccccc}
\hline \multirow{2}{*}{ Alcohol } & \multirow{2}{*}{$\begin{array}{c}\text { Number } \\
\text { of carbon }\end{array}$} & \multicolumn{2}{c}{ Critical point } & \multicolumn{2}{c}{ Reaction condition } \\
\cline { 2 - 6 } & 1 & 239 & $T_{\mathrm{C}}\left({ }^{\circ} \mathrm{C}\right)$ & $P_{\mathrm{c}}(\mathrm{MPa})$ & \multicolumn{2}{c}{$\left({ }^{\circ} \mathrm{C} / \mathrm{MPa}\right)$} \\
\hline Methanol & 2 & 243 & 6.38 & $2709 / 27$ & $350 / 43$ \\
Ethanol & 3 & 264 & 5.06 & $270 / 14$ & $350 / 25$ \\
1-Propanol & 4 & 287 & 4.90 & $270 / 12^{*}$ & $350 / 23$ \\
1-Butanol & 8 & 383 & 2.86 & $270 / 8^{*}$ & $350 / 19^{*}$ \\
1-Octanol & 10 & 414 & 2.22 & $270 / 4^{*}$ & $350 / 6^{*}$ \\
1-Decanol & & & & & \\
\hline
\end{tabular}

* subcritical condition 


\section{List of Figures}

Figure 1. Changes in the residues of beech wood treated in the various sub/supercritical alcohols at (a) $270^{\circ} \mathrm{C}$ and (b) $350^{\circ} \mathrm{C}$ (circles, methanol; squares, ethanol; triangles, 1-propanol; diamonds, 1-butanol; crosses, 1-octanol; pluses, 1-decanol).

Figure 2. Chemical composition in the alcohol-insoluble residue after treated with various sub/supercritical alcohols at $270^{\circ} \mathrm{C}$.

Figure 3. Chemical composition in the alcohol-insoluble residue after treated with various sub/supercritical alcohols at $350^{\circ} \mathrm{C}$.

Figure 4. Liquefaction rate constants of wood cell wall components in the various sub/supercritical alcohols at $350^{\circ} \mathrm{C}$.

Figure 5. GPC chromatograms of the various alcohol-soluble portions after the treatment at $350^{\circ} \mathrm{C}$ for $30 \mathrm{~min}$ (column, Shodex KF-801 connected with KF-802; eluent, tetrahydrofuran; detector, Ultraviolet light detector (UV, $\lambda=280 \mathrm{~nm}$ ); flow rate, $0.6 \mathrm{~mL} / \mathrm{min}$; temperature, $50^{\circ} \mathrm{C}$ ).

Figure 6. HPLC chromatograms of the (a) methanol, (b) ethanol, (c) 1-poropanol, (d) 1-butanol, (e) 1-octanol and (f) 1-decanol-soluble portions after the treatment at $270^{\circ} \mathrm{C}$ for $30 \mathrm{~min}$ (column, STR ODS-II; eluent, $\mathrm{CH}_{3} \mathrm{OH} / \mathrm{H}_{2} \mathrm{O}, 20 / 80-100 / 0$ (0-60 min); detector, UV(280nm); flow rate, $1.0 \mathrm{~mL} / \mathrm{min}$; temperature, $40^{\circ} \mathrm{C}$; CA, coniferyl alcohol; SA, sinapyl alcohol; CA-me, coniferyl alcohol $\gamma$-methyl ether; other abbreviations are described in a similar manner) 
Figure 7. HPLC chromatograms of (a) methanol and (b) ethanol-soluble portions after the treatment at $350^{\circ} \mathrm{C}$ for $30 \mathrm{~min}$ (column, URTRON PS-80P; eluent, $\mathrm{H}_{2} \mathrm{O}$; detector, reflux index detector; flow rate, $0.8 \mathrm{~mL} / \mathrm{min}$; temperature, $80^{\circ} \mathrm{C}$ ). 


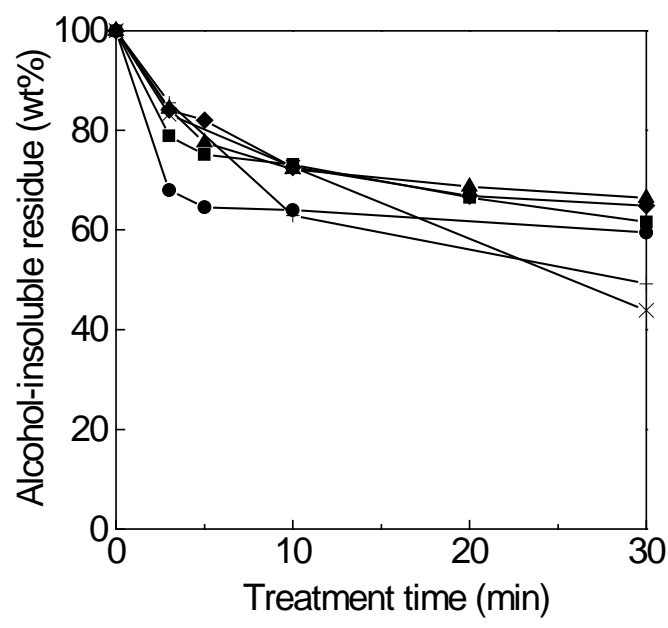

(a) $270^{\circ} \mathrm{C}$

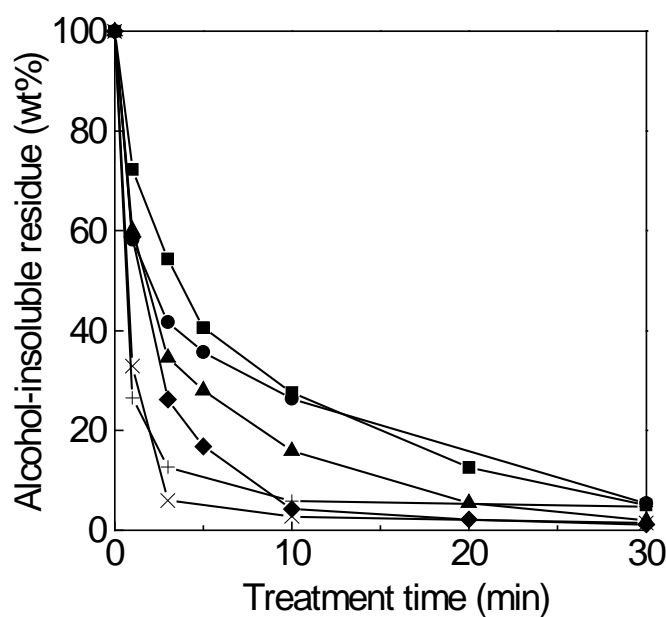

(b) $350^{\circ} \mathrm{C}$ 


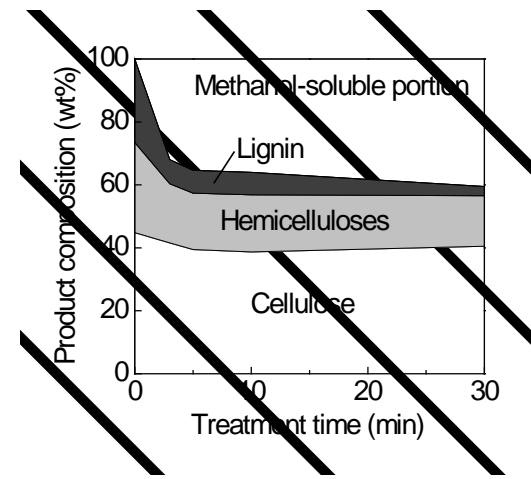

(a) Methanol, $270^{\circ} \mathrm{C} / 27 \mathrm{MPa}$

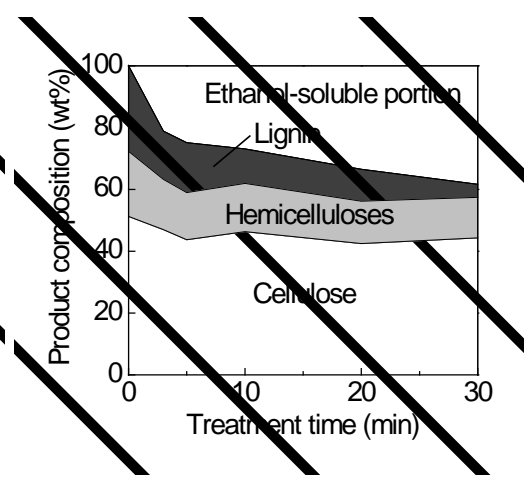

(b) Ethanol, $270^{\circ} \mathrm{C} / 20 \mathrm{MPa}$

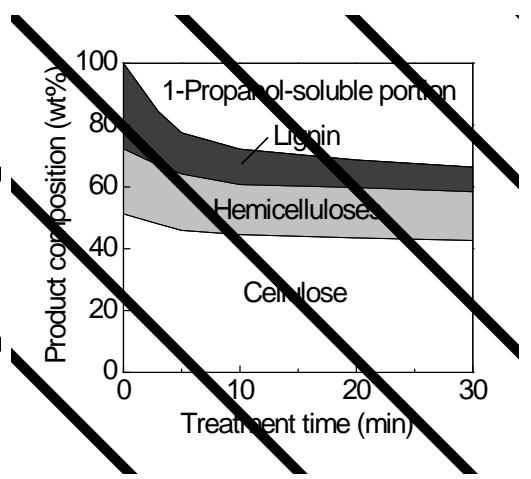

(c) 1-Propanol, $270^{\circ} \mathrm{C} / 14 \mathrm{MPa}$

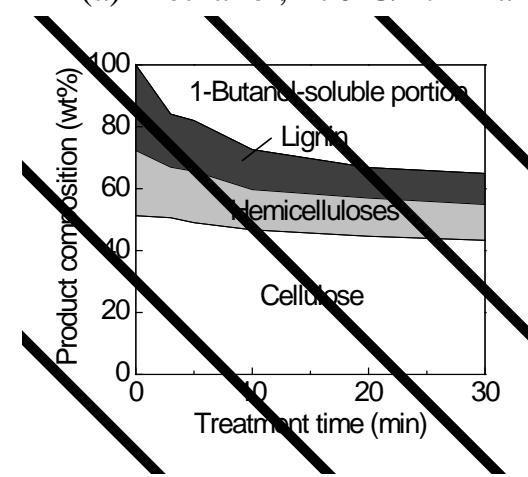

(d) 1 -Butanol, $270^{\circ} \mathrm{C} / 12 \mathrm{MPa}$

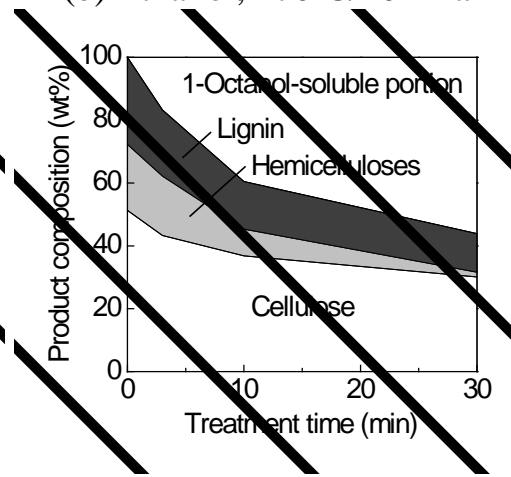

(e) 1 -Octanol, $270^{\circ} \mathrm{C} / 8 \mathrm{MPa}$

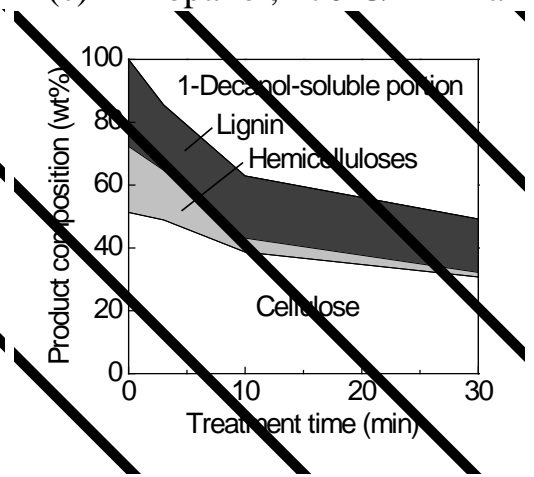

(f) 1-Decanol, $270^{\circ} \mathrm{C} / 4 \mathrm{MPa}$ 


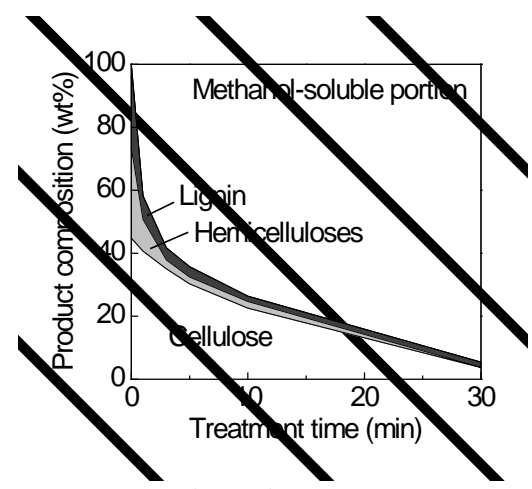

(a) Methanol, $350^{\circ} \mathrm{C} / 43 \mathrm{MPa}$

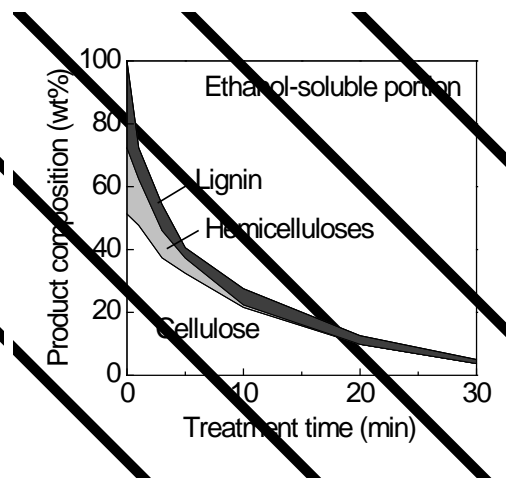

(b) Ethanol, $350^{\circ} \mathrm{C} / 25 \mathrm{MPa}$

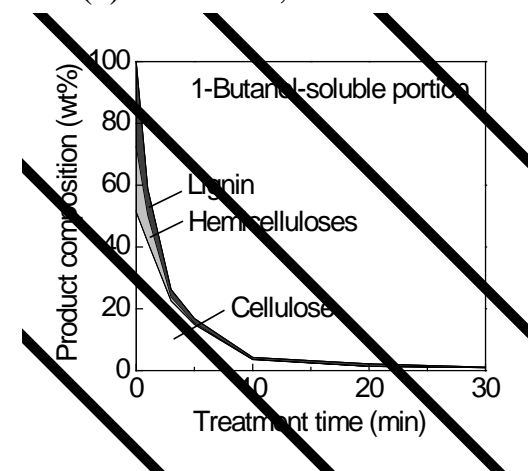

(d) 1-Butanol, $350^{\circ} \mathrm{C} / 23 \mathrm{MPa}$

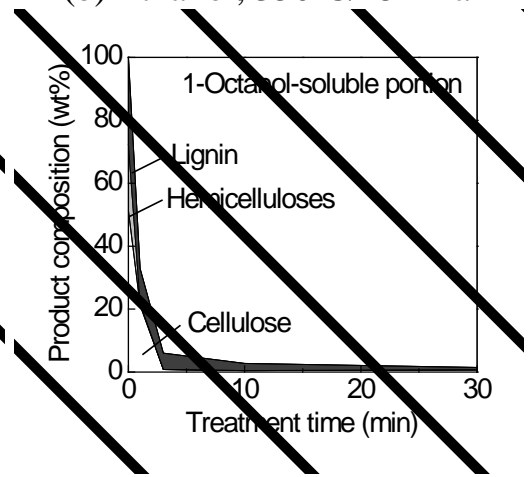

(e) 1 -Octanol, $350^{\circ} \mathrm{C} / 19 \mathrm{MPa}$

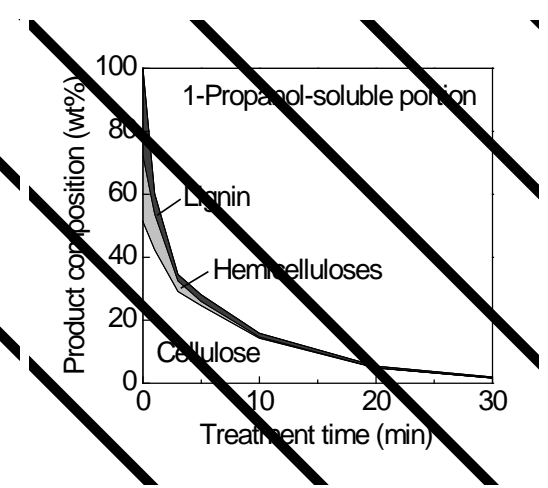

(c) 1-Propanol, $350^{\circ} \mathrm{C} / 23 \mathrm{MPa}$

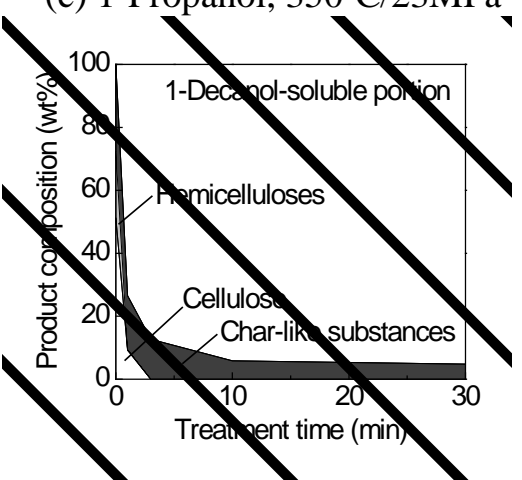

(f) 1-Decanol, $350^{\circ} \mathrm{C} / 6 \mathrm{MPa}$ 


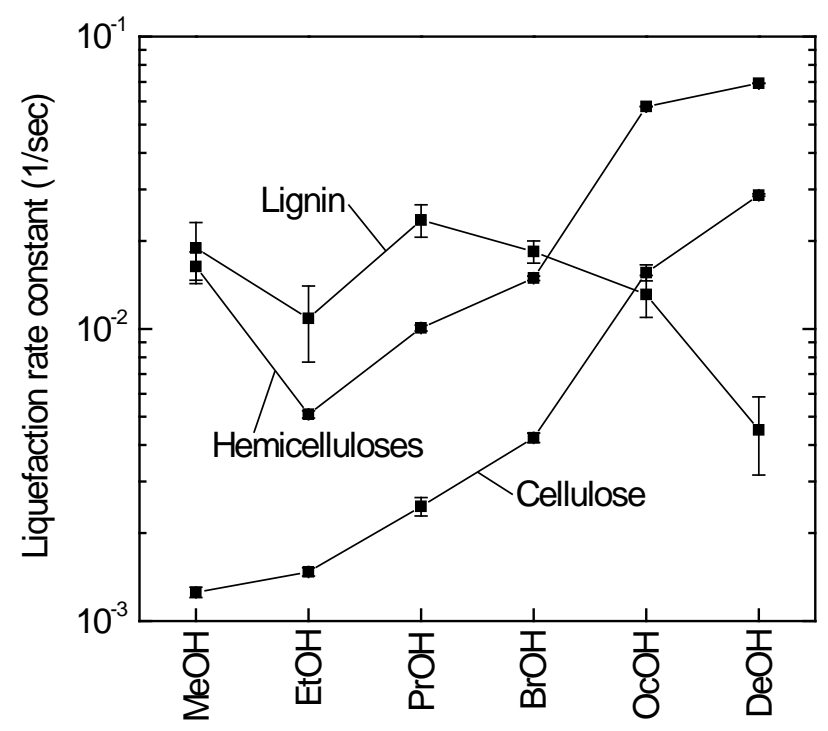




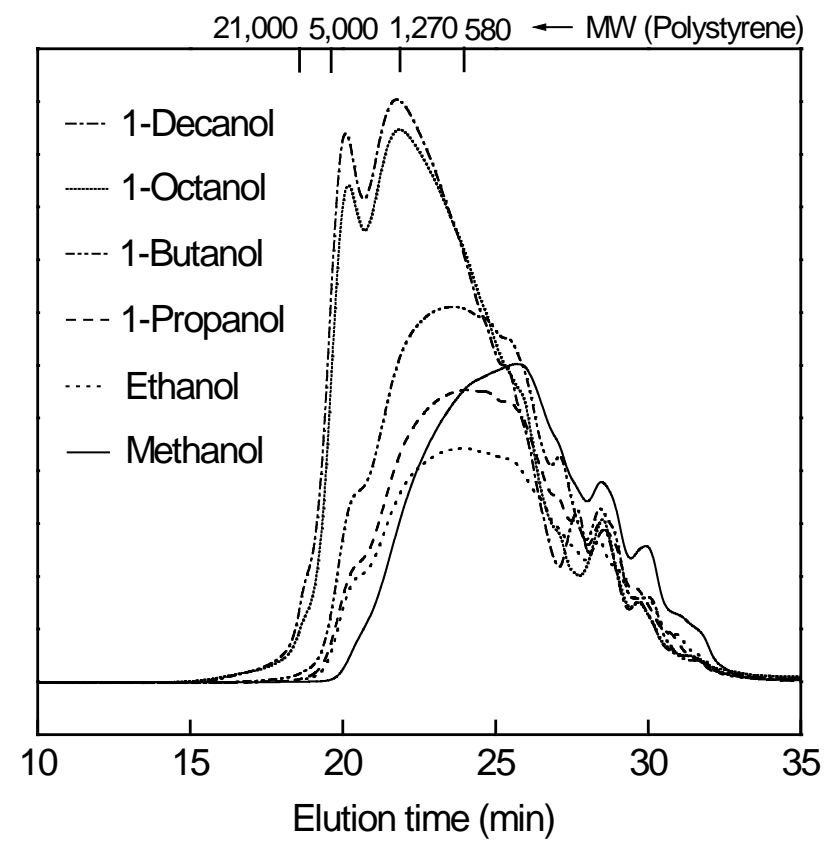




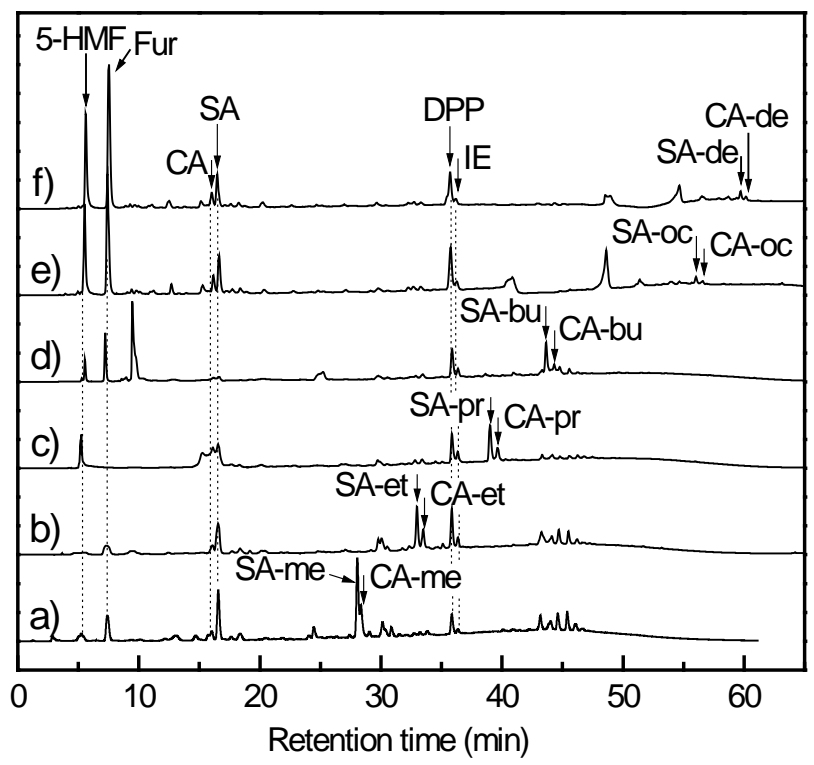




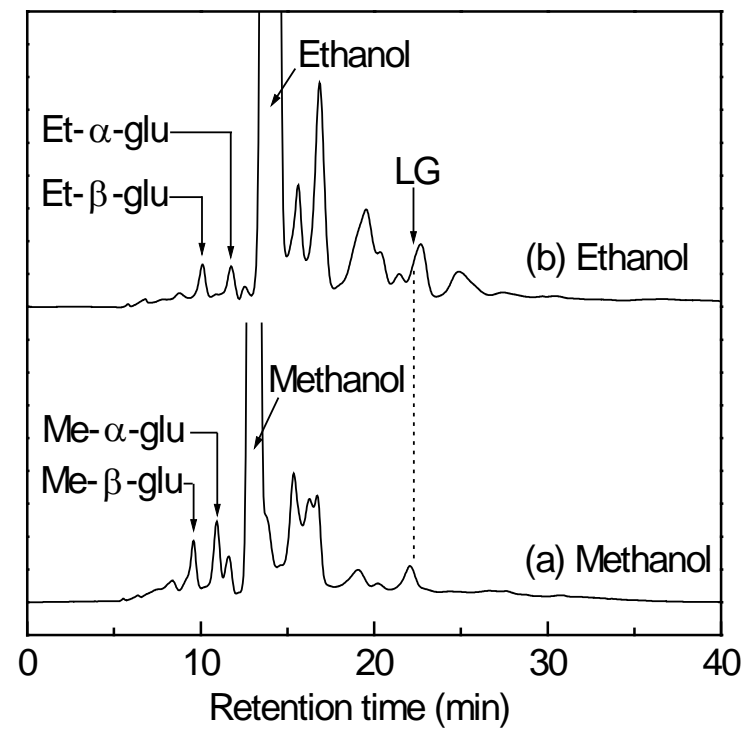

